\title{
Remote Work During COVID-19 Pandemic and the Right to Disconnect - Implications for Women's Incorporation in the Digital World of Work
}

\author{
Summary
}

Access is a key foundation to achieve digital inclusion, however, in many countries, including G20 economies, structural inequalities such as those in income, education and employment opportunities increase barriers to technology access and use, which women are likely to experience more severely.

When promoting policies to facilitate the participation of women in the paid economy, flexible working (including teleworking), is often promoted as a solution. However, studies in several countries show that the digital world of work could further cement traditional gender roles.

The digital gender divide has been recognized as a challenge to achieve gender equality for women, particularly as the 4th Industrial Revolution continues to increase the pace of change of information and communication technologies.

As societies become increasingly dependent on digital technology, women are at risk of losing out on the positive promise of full participation in digital economies.

Reports around the world are showing that during COVID-19 crisis, inequalities are being exacerbated, and so across the world, women are being affected more severely by the socioeconomic impacts of this Pandemic.

Many women are juggling an increase in unpaid care work while also contending with paid work, now in a new form: the Digital World of Work, Teleworking and its implications. The pressure of balancing work and family life is taking a severe toll on women's well-being.

Before the pandemic of COVID-19, women globally did nearly three times as much unpaid care and domestic work as men. But after the Pandemic, the care work at home has really grown exponentially. Besides the direct impacts of the pandemic, the response is also exacerbating inequalities. In particular, the closure of schools and nurseries has revealed the fragility of women's participation in the paid economy. The

* LL.M., First Assistant Professor, Department of Labour and Social Security Law, Faculty of Law, University of Buenos Aires, Argentina.

** PhD, Assistant Professor, Department of Labour Law and Social Law, Faculty of Law and Administration University of Warmia and Mazury in Olsztyn, Poland. 
school closures and household isolation are moving the work of caring for children from the paid economy - nurseries, schools, babysitters - to the unpaid one.

This really underpins so many of the inequalities that women experience. While both women and men are suffering the economic fallout of the virus across the world, it is women who are being disproportionately more constricted by it.

The right to disconnect, is design to establish boundaries around the use of electronic communication after working hours and to provide employees with the right to not engage in any work-related activities at home. It is often looked upon as an individual right of the employee to not only disconnect but also to not be reprimanded for failing to connect - or rewarded for constantly staying connected.

Because of social and cultural roles and stereotypes, women have more responsibility for their families and homes than men, and may not be able to stay connected after the formal working day ends even if they wanted to. This is particularly the case for single mothers, for whom a right to disconnect could have a proportionally larger positive impact than for other employees.

We intend to analyze how the structural and sociological phenomenon, that women experience, articulates with the Digital World of Work and the Right to Disconnect, paying special attention to family work balance and fair family responsibilities distribution.

Key words: remote work, pandemic, right to disconnect, gender equality, discrimination

\section{Introduction}

The regulation of working time and its due limitation is not a new issue to national or international regulation. Neither is the need to balance personal and work life. It is mainly women who have waged long battles to put these issues on the agenda for years.

The need to give due limitation to working time gave rise to the first protective labour standards through the establishment of Maximum Working Hours and its correlate the time to rest. ${ }^{1}$ However, the incorporation of new technologies in the World of Work, during the "Industrial Revolution 4.0," blurred the previously defined limits of the working day and exacerbated the imbalance between personal and work life.

The appearance of the COVID-19 pandemic accelerated the urgency of discussion about the need to make new and autonomous regulation - or to revitalize the existing regulations - to contain this new social conflict. ${ }^{2}$

1 ILO (1919), Convention on working hours (industry) (Nro 1).

2 Palomeque Lopez, MC (1991). The Reason for Labor Law in Labor Law and Ideology. According to Palomeque Lopez, Labor Law is a reaction to the social conflict of the industrial capitalist society. This specific social conflict was channeled/institutionalized/legalized, giving rise to our mother discipline. However, now it is necessary to 
From a Gender Perspective, the unpaid working hours socially assigned to women constitute a barrier for women's incorporation into the labour market. Now, to the social and structural phenomenon of unfair distribution of family responsibilities, we add the new careneeds derived from the pandemic situation and the problematic inherent in the massive implementation of remote work. The digital world of work may even exacerbate structural barriers to the incorporation and participation of women in the labor market.

In this article we intend to analyze the juxtaposition of diverse but simultaneous social phenomena from different angles, in order to address the need to introduce an intersectional and gender sensible approach in the regulation of the right to disconnect.

\section{Gender dynamics in the world of work}

The incorporation of women in the world of work, employment and production has increased notably. However, women's participation in the labour market is still marked by inequality in terms of access, duration, and promotion, as a reflection of a system that governs social relations between genders and assigns roles and stereotypes.

The maintenance and reproduction of existing inequalities between men and women in the world of work is influenced by several factors derived from the sexual division of labor and a gender order (which includes not only work, but other dimensions of life) that assigns to women the basic and primordial function of caring for the private and domestic sphere, while attributing to this a social value that is inferior or non-existent in comparison to the value of the "public" world. Markets are completely unaware of the economic value of women's contribution to society maintenance. ${ }^{3}$

The social structure has historically assigned women the greatest responsibilities in the domestic sphere, often on the grounds that they are naturally better prepared to assume them, while men have been assigned the tasks of protection and provision of food. This domestic category includes direct care for family members and third parties, as well as other activities related to housework that ensure the main-

analyze which new channeling corresponds to the new conflict or social sub-conflict derived from the implementation of technology in the world of work.

${ }^{3}$ D'Alessandro, Mercedes (2017). Feminist Economics. Argentina, South American. 
tenance and reproduction of individuals and societies ${ }^{4}$. Traditionally, these activities haven't been considered productive work and therefore remain largely unpaid and economically invisible.

When analyzing two crucial resources for economic autonomy, income and time, it is observed that asymmetries between men and women have both a monetary component and a component of dedication to different types of jobs which accentuates the gender gap in households. In fact, the unpaid work that involves caregiving and domestic work is predominantly performed by women. In all the countries for which data is available, women's unpaid work time is much greater than men's time on these same activities. ${ }^{5}$

The construction of these roles and their persistence continues to generate various economic effects that are difficult to measure. For example, the impact of carrying out household chores is not usually quantified, since it is not easy to attribute a monetary value to them. ${ }^{6}$ The lack of appreciation of these tasks, generally assumed by women, makes up much of the basis of gender inequity, which in turn generates different forms of employment discrimination.

It should be noted, then, that although the incorporation of women into the workplace was accompanied by a reduction in gender gaps, for women it also represented the assignment of a new work activity, in this case "paid," without their being able to leave aside their other, unpaid activity, although it is recognized as crucial for the development of societies.

Indeed, many forms of human activity with economic and social value are not yet recognized as "work." When analyzing this question, we need to remember that so-called "unpaid work" denotes the lack of ascription of market value to the work socially assigned to women, which has also been called reproductive work.

In this regard, Marilyn Waring claimed that the national gross domestic product measurement system is arbitrary, because it ignores the contribution of women to society and its functioning. ${ }^{7}$

${ }^{4}$ ILO (2019). Report to the World Commission on the Future of Work. Geneva.

${ }^{5}$ Observatory of Gender Equality for Latin America and the Caribbean.

${ }^{6}$ Salvador, Soledad (2007) Contributions for the elaboration of a satellite account of unpaid work in Uruguay. Center Interdisciplinary of Studies on Development.

7 Waring, Mariling (1999); Counting for Nothing: What men value and what women are worth, Toronto, University of Toronto Press. 
Katerine Marcal, author of Who made Adam Smith's dinner?, indicated that this double load of paid and unpaid work limits the possibilities of women to train for and enter the labour market, as well as later to achieve promotion within it. ${ }^{8}$

In this sense, Silvia Federici demands the assignment of a market price to reproductive work "because only then would it seem to have value in this capital society," ${ }^{\prime \prime}$ and not just in the case of outsourcing of those services (an operation that falls on other women, who also suffer the undervaluation of their work in terms of market value).

In general, time spent planning the week's meal, doing laundry, or helping children with homework is not counted within working hours. Its monetary value only appears when these tasks are outsourced, either to care centers (kindergartens, geriatric care units) or to a private service (domestic workers, nurses, babysitters).

The ILO has also taken this situation into account. In 2013, the 19th International Conference of Labor Statisticians (ICLS) adopted Resolution I, which defines care services and unpaid domestic services for household members and family members as "provision of services for own final use ${ }^{\prime 10}$. The Resolution clearly states that work can be done in any type of economic unit, including households and communities, ${ }^{11}$ and may also include services that are not provided in the context of market transactions. ${ }^{12}$ In 2018, the 20th ICLS ${ }^{13}$ went further on its Resolution I, providing a new International Classification of Situation at Work, which covers all jobs and work activities in all their forms, including the provision of services for own final use. ${ }^{14}$ In addition to

${ }^{8}$ Marcal, Katerine (2016), Who made Adam Smith's dinner? A history of women and the economy, Buenos Aires, Debate.

${ }^{9}$ Federici, Silvia (2012), Revolution at Point Zero: Housework Reproduction; and Feminist Struggle. California, PM Press.

${ }^{10}$ ILO (2013). Resolution I. Resolution on the statistics of work, occupation and underutilization of the labor force. Adopted by the 19th International Conference of Labor Statisticians, October (Geneva).

11 Nussbaum, MC 2017. "Preface", in M. Lansky, J. Ghosh, D. Méda and U. Rani (eds.): Women, gender and work: Social choices and inequalities, vol. 2, pp. vii-x (Geneva, ILO).

12 Ibidem.

${ }^{13}$ ILO (2018). Resolution concerning statistics of labor relations, Resolution I, 20th International Conference of Labor Statisticians, 10-19 October (Geneva).

14 The provision of "services" for own end use (beyond the production boundary of the 2008 System of National Accounts, but within the general production boundary), 
this, the ILO has initiated work on different technologies in order to test alternative approaches to measuring participation in unpaid work and the time spent on it. ${ }^{15}$

Despite the measures implemented to alleviate this unequal and unfair conceptualization of female work in society, the inequalities within households persists and is one of the major sources of inequality between men and women. As women must dedicate more time to unpaid work, they have less time to study, train or work a paid job; or they are forced to accept more "flexible" jobs - in general, precarious and low-wage jobs - and they end up facing the reality of a double working day, because they carry out tasks both inside and outside the household.

In the group of women who lack their own income, unpaid work time is higher compared to women who do have their own income. ${ }^{16}$ The sexual division of labor aggravates the circumstances of low-income women and those who do not have economic independence, and who in situations of violence have limited means to react. ${ }^{17}$

Still today, the main burden of home and care work has fallen on families and, within them, on women. Consequently, that care time constitutes a variable dependent on the capabilities and resources of families and, in turn, on the chance for finishing education and for

covers: i) household accounting and management, the purchase and/or transportation of household goods; ii) food preparation and/or service, waste disposal and recycling of household waste; iii) cleaning, decoration and maintenance of the home and facilities, durable household goods and gardening; iv) the care and education of children; the transportation and care of household members (elderly, dependents or others), and domestic animals or household pets, etc. The expression "for own final use" should be interpreted as production whose intended destination is mainly for the final use of the producer himself, such as fixed capital formation, or the final consumption of household members or relatives living in other households (ILO).

${ }^{15}$ ILO (2016). Own use production work (II) - Services for own final use. Paper presented at the Workshop analysis of experimental studies on the labor force survey, Statistics Department 15-18 November (Geneva).

${ }^{16}$ ILO and Gallup (2017): Towards a better future for women and work: Voices of women and men, available at https://www.ilo.org/wcmsp5/groups/public/---dgreports/---dcomm/---publ/documents/publication/wcms_546256.pdf (p. 45) (full report in English and press release in Spanish entitled "Towards a better future for women at work: the opinion of women and of men", available at https://www.ilo.org/wcmsp5/groups/ public/---dgreports/---dcomm/---publ/documents/publication/wcms_607487.pdf).

${ }^{17}$ ILO (2017) Global employment trends for youth 2017: Paths to a better working future. Geneva. 
labor integration and development among young women. To address this structural limitation, it is necessary to posit care as a basic social need and, therefore, as a civil right.

As the Report of the World Commission on the Future of Work (ILO) states: "While many doors have been opened to improve the participation of women in the labor market, women still do three-quarters of non-professional care work. paid from all over the world. While in many countries women are encouraged to enter male-dominated fields, men are rarely encouraged to do jobs traditionally considered female". The Report adds that: "The work that women do is often seen as 'subordinate' to men's work, despite the number of female-headed households around the world." 18

This shows that, despite the growing female participation in marketed work, this has not been matched by a greater male participation in unpaid domestic and care work within the household. The overload of working hours for women acts as a barrier to participation in the labor market on equal terms with men and access to economic resources that would allow them greater degrees of autonomy.

\section{Conciliation between personal and work life and new technologies}

A recent ILO and Gallup survey found that balancing work and family is the biggest challenge for women in developed and emerging countries and the second biggest challenge in developing countries. ${ }^{19}$

The recent UN Women report ${ }^{20}$ suggests that the organization of care and domestic work constitutes a structural block to the economic empowerment of all women. Gender inequality in the world of work

${ }^{18}$ ILO (2019). Report of the Commission for the Future of Work: Work for a Better Future. Available at https://www.ilo.org/wcmsp5/groups/public/---dgreports/---cabinet/documents/publication/wcms_662410.pdf.

${ }^{19}$ ILO and Gallup, 2017: Towards a better future for women and work: Voices of women and men, available at https:/www.ilo.org/wcmsp5/groups/public/---dgreports/--dcomm/---publ/documents/publication/wcms_546256.pdf (p. 45) (full report in English and press release in Spanish entitled "Towards a better future for women at work: the opinion of women and men", available at https://www.ilo.org/wcmsp5/groups/public/---dgreports/---dcomm/---publ/documents/publication/wcms_607487.pdf).

${ }^{20}$ UN-Women (2018). Turning promises into action: Gender equality in the 2030 Agenda for Sustainable Development New York. 
is a nodal factor in the feminization of poverty, and it is accentuated by the gap in labor participation, horizontal and vertical occupational segregation, underemployment, unemployment and informality.

Likewise, this social phenomenon of an overload of working hours (mainly "unpaid") on women, implies that there are margins of greater incorporation of women in part-time or flexible "paid" work since this allows them to continue with their own tasks of reproductive work and caring for the sick or elderly. ${ }^{21}$ The same occurs with other forms of work that allow women to stay longer in the home, with formats such as remote work.

Women may work part-time by choice, but many do so because they assume an unequal share of family responsibilities. In some countries, because of gender stereotypes, part-time work is the only option available to women. Most part-time workers are women. ${ }^{22}$ Therefore, although the benefits of this possibility are recognized, they should be understood as a palliative to a symptom instead of a remedy for an underlying disease. Furthermore, this trend contributes to unequal pay.

Moreover, if used without a gender-sensitive approach, it could reproduce the same barriers for women that we have seen before, or even exacerbate them by aggravating the imbalance between work and life, due to the elimination of the traditional distinction between working and non-working hours.

In terms of equity, in addition to these general problems, there is the risk that digital work will reinforce gender roles and the expectation that women should only carry out paid work within their homes. ${ }^{23}$ At the same time, there is reason to believe that the lower rate of acceptance of sporadic jobs with higher added value among women also reflects the fact that fewer women study in STEM fields. ${ }^{24}$

${ }^{21}$ ILO (2019). Centenary Declaration. Geneva.

${ }^{22}$ ILO (2019). A Quantum Leap for Gender Equality: For a Better Future of Work for All. Geneva.

${ }^{23}$ Seron, C., Silbey , S.S., Cech, E., Rubineau, B. 2016. “Persistence is cultural: Professional socialization and the reproduction of sex segregation", Work and Occupations, vol. 43, no. 2, pp. 178-214.

${ }^{24}$ ILO (2019). A Quantum Leap for Gender Equality: For a Better Future of Work for All. Geneva. 
These forms of work must necessarily be combined with a fair distribution of family responsibilities and a gender perspective, in order to be able to mean real advance towards gender equality.

ILO Convention 156 on the distribution of family responsibilities constitutes a great advance in this matter, sending a message to the labor market of non-discrimination of workers with family responsibilities $^{25}$. Recently, the Centenary Declaration of the ILO advanced this point and placed at the center of the agenda the need for the States to adopt an active and complementary role in regards to the need for equitable distribution of care responsibilities. It also promoted the incorporation of public policies that help families' maintenance of care tasks that otherwise (and due to social dynamics) would fall on women. Thus, it was proposed to discard the binomial "woman/man" and move to the binomial "state / family."

Having public support and infrastructures for care services is vital to changing these deeply rooted gender roles and dynamics which limit women's participation in the labour market.

\section{The pandemic and gender issues}

Crises amplify existing inequalities, and therefore around the world, women are more severely affected by the socio-economic impacts of the current pandemic.

This is because in all countries women earn less, save less, and are more likely to be in precarious jobs with little security or protection if they work, or to work in the informal sector without any protection. And that means they have fewer buffers against economic shocks, like the ones we have been experiencing.

In fact, the gender consequences of the pandemic intersect with other inequalities, and especially with the invisible but overwhelming burden of unpaid work, most of which is assumed by women in every country in the world, due to long-term social and cultural roles and stereotypes ingrained in our societies.

Thus, while both women and men are suffering the economic consequences of the virus around the world, it is women who are disproportionately affected by it. Before the pandemic, women worldwide

${ }^{25}$ ILO (1981) Workers with Family Responsibilities Convention, 1981 (No. 156). 
did nearly three times more unpaid care and domestic work than did men. But after the pandemic, home care work has grown exponentially. ${ }^{26}$

The uneven distribution of the increase in demand for social care services during the crisis affects women more severely. The closure of early childhood education centers and schools, as well as the interruption of the provision of social care services and the unavailability of older family members to provide help, has increased the demand for care services during the crisis. ${ }^{27}$

Furthermore, if schools stay closed but the economy opens, there is an expectation that one parent will stay at home. Because of traditional norms, gender roles, and unequal pay, the woman will most likely be the one to end up staying at home. And single mothers, in particular, do not have anyone to share the burden of care and are more likely to work for low wages and in vulnerable occupations. ${ }^{28}$

Writer Helen Lewis has pointed out that "school closings and home isolation are shifting the work of caring for children from the paid economy (nurseries, schools, babysitters) to the unpaid one." 29

The United Nations confirms that since institutional and community childcare has not been accessible to many families during the closure, the provision of unpaid childcare has fallen more heavily on women, limiting their ability to work. ${ }^{30}$ In addition, the ILO has also highlighted the risk of increased domestic violence during the crisis, particularly because of confinement measures.

${ }^{26}$ ILO (2020). The COVID-19 response: Getting gender equality right for a better future for women at work. Available at https://www.ilo.org/wcmsp5/groups/public/--dgreports/---gender/documents/publication/wcms_744685.pdf.

27 Ibidem.

${ }^{28}$ ILO (2020). ILO Observatory: COVID-19 and the world of work. Fifth edition Updated estimates and analysis. Available at https://www.ilo.org/wcmsp5/groups/ public/@dgreports/@dcomm/documents/briefingnote/wcms_749470.pdf.

${ }^{29}$ Helen Lewis (2020). The Coronavirus Is a Disaster for Feminism. Pandemics affect men and women differently. Article for The Atlantic. Available at https://www. heatlantic.com/international/archive/2020/03/feminism-womens-rights-coronavirus -covid19/608302/.

${ }^{30}$ UNWomen (2020). Policy brief: The impact of COVID-19 on women. Available at https://www.unwomen.org/en/digital-library/publications/2020/04/policy-brief-theimpact-of-covid-19-on-women. 
Remote Work During the COVID-19 Pandemic and the Right to Disconnect...

Data from a recent labor force survey underline a worsening employment situation for women. ${ }^{31}$ Many women are juggling rising unpaid care work and paid work, now under a new form: the Digital World of Work, remote work and its implications. The pressure to reconcile work and family life is seriously affecting the well-being of women.

\section{Remote work during pandemic}

In 2017 the ILO-Eurofound report "Working anytime, anywhere" showed that the use of modern communication technologies has both positive and negative effects for the workers health and safety. On the one hand, it may facilitate more flexibility in the organization of work and working time management which may lead to better work-life balance, but at the same time make the boundaries between work and personal life disappear, leading to a higher risk of working over-time, a high level of stress and the need to be always "on call." ${ }^{32}$ These critical aspects of regular working from home have also been confirmed in the latest Eurofound surveys' results ${ }^{33}$, which show that when working from home, remote workers are more likely to work in their free time, even more than 48 hours per week, which may have negative psychosocial consequences.

According to the European Parliament's report on "Health and safety in the workplace of the future," long-range managerial monitoring, a demand for constant availability of workers and blurred boundaries between private life and work may present psychosocial health and safety risks, including for anxiety, depression, and burnout. ${ }^{34}$ As

${ }^{31}$ Ibidem.

32 J. Messenger et al. (2017). Working anytime, anywhere: The effects on the world of work , ILO-Eurofound Research report, Luxemburg. Available at: https://www.ilo. org/global/publications/books/WCMS_544138/lang--en/index.htm.

${ }_{33}$ Eurofound (2020). Living, working and COVID-19, Luxembourg. Available at: https://www.eurofound.europa.eu/publications/report/2020/living-working-and -covid-19\#tab-01; see also: Eurofound (2020), Telework and ICT-based mobile work: Flexible working in the digital age, New forms of employment series, Luxembourg. Available at: https://www.eurofound.europa.eu/publications/report/2020/teleworkand-ict-based-mobile-work-flexible-working-in-the-digital-age.

${ }^{34}$ D. Cabrelli, R. Graveling (2019). Health and safety in the workplace of the future. Available at: https://www.europarl.europa.eu/RegData/etudes/BRIE/2019/638434/ IPOL_BRI(2019)638434_EN.pdf 
the European Observatory of Working Life EurWork indicates: "The widespread use of smart phones and other digital devices means that always being 'on call' has become a reality in many workplaces, as continuous remote access can create pressure for employees to be constantly accessible." ${ }^{35}$

The need to respect workers' right to disconnect has become crucial in the time of the COVID-19 pandemic. Its The scope of the right to disconnect is to establish boundaries around the use of electronic communication tools outside of normal working hours. But the right to disconnect, in order to be fully exercised, needs to include the protection of the worker from negative consequences when failing to connect, as opposed to the "always on call" working scheme. ${ }^{36}$

The analysis of the Eurofound dataset shows that almost $40 \%$ of workers in the European Union have started working from home during the pandemic, with around $34 \%$ of European workers working from home only. ${ }^{37}$ One of the key findings of the research clearly states that because of the blurred lines between private life and work that remote workers are facing, "It will be critical for governments and social partners to introduce 'right to disconnect' initiatives in order to prevent large segments of workers becoming at risk of physical and emotional exhaustion." ${ }^{\prime 38}$

\section{Right to disconnect and gender equality}

As has been discussed above, because of social and cultural roles and stereotypes, women have more responsibility for their families and domestic duties than do men. Thus, when we consider the use of ICT technologies and digital communication tools in the working process,

${ }^{35}$ https://www.eurofound.europa.eu/observatories/eurwork/industrial-relationsdictionary/right-to-disconnect.

${ }^{36}$ ILO (2020), Teleworking during the COVID-19 pandemic and beyond, A Practical Guide, Geneva. Available at: https://www.ilo.org/wcmsp5/groups/public/---ed_protect/ ---protrav/---travail/documents/instructionalmaterial/wcms_751232.pdf.

37 Eurofound (2020), Working during COVID-19 dataset. Available at: https://www. eurofound.europa.eu/data/covid-19/working-teleworking. See also Eurofound (2020). Living, working and COVID-19. Available at: https://www.eurofound.europa.eu/ publications/report/2020/living-working-and-covid-19\#tab-01, p. 13.

${ }^{38}$ Eurofound (2020), Living, working and COVID-19 dataset, Dublin. Available at: http://eurofound.link/covid19data. 
Remote Work During the COVID-19 Pandemic and the Right to Disconnect...

women may not stay connected after formal working hours to the same extent as male workers. This is a particularly important barrier for single mothers and parents of children under 12 years of age, for whom the right to disconnect could have a crucial role in terms of work-life balance and gender equality.

In fact, in the survey launched by Eurofound in April and June 2020 regarding the influence of the COVID-19 pandemic on the working conditions and work-life balance, one of the questions was: "How often in the last 2 weeks, have you found it difficult to concentrate on your job because of your family responsibilities?." 39 The data shows that the response differs by gender and age - the largest group that reported experiencing these difficulties always or most of the time was females aged 35-49. Women with children under 12 years of age reported more difficulties in combining work and private life, problems with concentration on the job because of the family, and struggling with the work-life balance. It was particularly problematic in the case of workers working from home only. If we add to the regular working performance the amount of time dedicated to housework and the evident disproportion between men and women in this field, ${ }^{40}$ one may notice the barriers against female workers participating in the digital world of work to the same extent as men. The demand to be always available and "on call" negatively affects women, in particular when work is performed from home only.

In recent years, some European countries have launched formal and informal measures to guarantee to workers the right to disconnect (these include France, Spain, Italy and Germany), but common European measures have not been taken.

European social partners have increased their efforts to evaluate the consequences of regular remote work and to propose solutions to the growing risks to the health and safety of workers of being too connected.

39 Eurofound (2020), Working during COVID-19 dataset. Available at: https://www. eurofound.europa.eu/data/covid-19/working-teleworking.

${ }^{40}$ The Eurofound report states that women dedicated more time than men to housework both when they were employed (16 hours compared to 11 hours), and when they were unemployed or inactive (20 hours compared to 12 hours for men). Eurofound (2020), Working during COVID-19 dataset, pp. 22-24. Available at: https://www.eurofound.europa.eu/data/covid-19/working-teleworking. 
The trade union Uni Global Union in October 2019 proposed a catalogue of best practices in terms of the right to disconnect. One of these recommendations is to ensure agender perspective and equal opportunities while regulating the right to disconnect, in order to promote family co-responsibility. ${ }^{41}$

In June, 2020, European social partners signed the European Social Partners Framework Agreement, ${ }^{42}$ which also addressed the right to disconnect. Measures that have to be taken include training and awareness raising on the proper use of digital tools by workers, aimed at respecting working time also in case of remote work, commitment from management to create a culture that avoids contact with the worker after regular working hours, and adoption of strategies to ensure equal opportunities and benefits from the use of modern technologies both for men and for women. ${ }^{43}$

\section{Conclusions}

Remote work has not only become more common, but is set to become permanent in many countries, during and after the COVID-19 pandemic. In order to separate work and personal life and to protect the health and safety of the worker from risks associated with an overly connected working culture, concrete measures including the right to disconnect should be taken in the nearest future. As the analysis of complex data shows, the gender perspective is a must.

The latest initiative of the European Parliament, which on 21 January 2021 adopted a resolution with recommendations to the Commission on the right to disconnect (2019/2181(INL)), ${ }^{44}$ shows that the right to disconnect and its gender implication has become a notable question on the European level. The European Parliament has clearly stated that the growing use of digital tools in the work process has led to an 'ever-connected,' 'always on,' or 'constantly on-call' culture. The

${ }^{41}$ UNI Global Union (2019), The Right to Disconnect: Best Practices, p. 5. Available at: https://www.uniglobalunion.org/sites/default/files/imce/right_to_disconnect-en.pdf.

${ }^{42}$ European Social Partners Framework Agreement on Digitalisation (2020). Availableat:https://www.etuc.org/en/document/eu-social-partners-agreement-digitalisation.

${ }^{43}$ Ibidem, p. 9-10.

${ }^{44}$ European Parliament resolution of 21 January 2021 with recommendations to the Commission on the right to disconnect (2019/2181(INL)). Available at: https://www. europarl.europa.eu/doceo/document/TA-9-2021-0021_EN.html. 
negative consequences of this phenomenon influence workers' fundamental rights, such as the limitation of working time, the right to rest, fair remuneration and fair working conditions, physical and mental health and safety at work, and work-life balance. But the European Parliament has also pointed out that the current working conditions have a disproportionately negative impact on workers with caring responsibilities, who tend to be women, and thus on the principle of equality between women and men. Proposing a draft of the directive on the right to disconnect, the European Parliament calls on the Commission to address this important question in European legislation and to include the right to disconnect in the New Occupational Safety and Health Strategy.

\section{Bibliography}

Cabrelli D., Graveling R. (2019). Health and safety in the workplace of the future. Available at: https://www.europarl.europa.eu/RegData/etudes/ BRIE/2019/638434/IPOL_BRI(2019)638434_EN.pdf.

D'Alessandro, Mercedes (2017). Feminist Economics. Argentina, South American.

Eurofound (2020), Industrial relations dictionary. Right to disconnect, https:// www.eurofound.europa.eu/observatories/eurwork/industrial-relationsdictionary/right-to-disconnect.

Eurofound (2020), Living, working and COVID-19 dataset, Dublin. Available at: http://eurofound.link/covid19data.

Eurofound (2020), Telework and ICT-based mobile work: Flexible working in the digital age, New forms of employment series, Luxembourg. Available at: https://www.eurofound.europa.eu/publications/report/2020/teleworkand-ict-based-mobile-work-flexible-working-in-the-digital-age.

Eurofound (2020), Working during COVID-19 dataset. Available at: https:// www.eurofound.europa.eu/data/covid-19/working-teleworking.

Eurofound (2020). Living, working and COVID-19, Luxembourg. Available at: https://www.eurofound.europa.eu/publications/report/2020/living-working-and-covid-19\#tab-01.

European Parliament resolution of 21 January 2021 with recommendations to the Commission on the right to disconnect (2019/2181(INL)). Available at: https://www.europarl.europa.eu/doceo/document/TA-9-2021-0021_ EN.html.

European Social Partners Framework Agreement on Digitalisation (2020). Available at: https://www.etuc.org/en/document/eu-social-partners-agreementdigitalisation. 
Federici, Silvia (2012), Revolution at Point Zero: Housework Reproduction; and Feminist Struggle. California, PM Press.

ILO (1919), Convention on working hours (industry) (Nro 1).

ILO (1981) Workers with Family Responsibilities Convention, 1981 (No. 156).

ILO (2013). Resolution I. Resolution on the statistics of work, occupation and underutilization of the labor force. Adopted by the 19th International Conference of Labor Statisticians, October (Geneva).

ILO (2016). Own use production work (II) - Services for own final use. Paper presented at the Workshop analysis of experimental studies on the labor force survey, Statistics Department 15-18 November. Geneva.

ILO and Gallup (2017): Towards a better future for women and work: Voices of women and men. Available at: http://www.ilo.org/wcmsp5/groups/public/ ---dgreports/---dcomm/---publ/documents/publication/wcms_546256.pdf (p. 45) (full report in English and press release in Spanish entitled «Towards a better future for women at work: the opinion of women and of men". Available at: https://www.ilo.org/wcmsp5/groups/public/---dgreports/--dcomm/---publ/documents/publication/wcms_607487.pdf).

ILO (2017) Global employment trends for youth 2017: Paths to a better working future. Geneva.

ILO (2018). Resolution concerning statistics of labor relations, Resolution I, 20th International Conference of Labor Statisticians, 10-19 October. Geneva.

ILO (2019). A Quantum Leap for Gender Equality: For a Better Future of Work for All. Geneva.

ILO (2019). Centenary Declaration. Geneva.

ILO (2019). Report of the Commission for the Future of Work: Work for a Better Future. Available at https://www.ilo.org/global/publications/ books/WCMS_662410/lang--en/index.htm.

ILO (2019). Report to the World Commission on the Future of Work. Geneva.

ILO (2020). ILO Observatory: COVID-19 and the world of work. Fifth edition Updated estimates and analysis. Available at https://www.ilo.org/ wcmsp5/groups/public/@dgreports/@dcomm/documents/briefingnote/ wcms_749470.pdf.

ILO (2020), Teleworking during the COVID-19 pandemic and beyondA Practical Guide, Geneva. Available at: https://www.ilo.org/wcmsp5/groups/ public/---ed_protect/---protrav/---travail/documents/instructionalmaterial/ wcms_751232.pdf.

ILO (2020). The COVID-19 response: Getting gender equality right for a better future for women at work. Available at https://www.ilo.org/ wcmsp5/groups/public/---dgreports/---gender/documents/publication/ wcms_744685.pdf.

Lewis, Helen (2020). The Coronavirus Is a Disaster for Feminism. Pandemics affect men and women differently. Article for The Atlantic. Available at 
Remote Work During the COVID-19 Pandemic and the Right to Disconnect...

https://www.theatlantic.com/international/archive/2020/03/feminism-womens-rights-coronavirus-covid19/608302/.

Marcal, Katerine (2016), Who made Adam Smith's dinner? A history of women and the economy, Buenos Aires, Debate.

Messenger J. et al. (2017). Working anytime, anywhere: The effects on the world of work, ILO-Eurofound Research report, Luxemburg. Available at: https://www.ilo.org/global/publications/books/WCMS_544138/lang--en/ index.htm.

Nussbaum, MC 2017. "Preface", in M. Lansky, J. Ghosh, D. Méda and U. Rani (eds.): Women, gender and work: Social choices and inequalities, vol. 2, pp. vii-x. Geneva, ILO.

Palomeque Lopez, MC (1991). The Reason for Labor Law in Labor Law and Ideology.

Salvador, Soledad (2007) Contributions for the elaboration of a satellite account of unpaid work in Uruguay. Center Interdisciplinary of Studies on Development.

Seron, C.; Silbey, SS; Cech, E.; Rubineau, B. 2016. “Persistence is cultural: Professional socialization and the reproduction of sex segregation", Work and Occupations, vol. 43, no. 2, pp. 178-214.

UNI Global Union (2019), The Right to Disconnect: Best Practices, p. 5. Available at: https://www.uniglobalunion.org/sites/default/files/imce/right_ to_disconnect-en.pdf.

UN-Women (2018). Turning promises into action: Gender equality in the 2030 Agenda for Sustainable Development New York.

UN-Women (2020). Policy brief: The impact of COVID-19 on women. Available at https://www.unwomen.org/en/digital-library/publications/2020/04/ policy-brief-the-impact-of-covid-19-on-women.

Waring, Mariling (1999); Counting for Nothing: What men value and what women are worth, Toronto, University of Toronto Press.

\section{Travail à distance pendant la pandémie COVID-19 et droit à la déconnexion - implications pour la participation des femmes au monde du travail numérique}

\section{Résumé}

L'accès aux nouvelles technologies est essentiel pour parvenir à l'inclusion numérique. Cependant, dans de nombreux pays, y compris les économies des pays du G20, les inégalités structurelles (par exemple en termes de revenus, d'éducation et de possibilités d'emploi) augmentent les obstacles à l'accès et à l'utilisation des technologies, ce qui touchent particulièrement les femmes. Les formes de travail flexibles (y compris le travail à distance) sont souvent promues parmi les solutions facilitant l'activité rémunérée des femmes. Cependant, des études menées dans plusieurs pays montrent que le monde du travail numérique peut renforcer davantage les rôles de genre traditionnels. L'inégalité entre les sexes dans la sphère numérique a été identifiée comme un obstacle 
majeur à la réalisation de la justice sociale, d'autant plus que la quatrième révolution industrielle continue d'accélérer le rythme du changement dans les technologies de l'information et de la communication. Alors que les sociétés deviennent de plus en plus dépendantes des technologies numériques, la vision de la pleine participation des femmes aux économies numériques s'éloigne.

Des rapports de diverses régions du monde montrent que pendant la crise provoquée par la pandémie COVID-19, ces inégalités se creusent et qu'à l'échelle mondiale, les femmes sont plus touchées par l'impact socio-économique de la pandémie que les hommes. De nombreuses femmes sont contraintes de combiner l'augmentation des soins non rémunérés avec les exigences d'un emploi rémunéré, qui prend désormais le plus souvent de nouvelles formes (monde du travail numérique, travail à distance), et leurs conséquences. La nécessité de concilier travail et vie de famille a un impact sérieux sur le bien-être des femmes.

Avant la pandémie COVID-19, les femmes du monde entier prestaient presque trois fois plus de soins et de travaux ménagers non rémunérés que les hommes. Suite à l'éclosion de la pandémie, la quantité de travail de soins à domicile a augmenté de façon exponentielle. Les femmes sont non seulement confrontées aux défis immédiats de la pandémie, mais elles connaissent également des inégalités croissantes. En particulier, la fermeture d'écoles et de jardins d'enfants a révélé la fragilité de la participation des femmes à l'économie salariale. La fermeture des établissements de garde d'enfants et l'isolement à domicile ont déplacé le travail de garde d'enfants de l'économie rémunérée (jardins d'enfants, écoles, garderies) vers le secteur non rémunéré. C'est là que la source de nombreuses inégalités vécues par les femmes doit être recherchée. Alors que les femmes et les hommes du monde entier sont durement touchés par l'impact économique de la pandémie, les femmes rencontrent plus de contraintes dans la sphère de l'activité rémunérée.

L'idée du droit à la déconnection consiste à définir les limites de l'utilisation de la communication électronique après les heures de travail et à donner aux salariés le droit de ne pas être sollicité à domicile. Ce droit est souvent compris non seulement comme le droit à la déconnection ; il vise également à protéger l'employé contre une réprimande pour ne pas être resté connecté et enlève la possibilité de le récompenser pour sa disponibilité hors les heures du bureau.

Les rôles et stéréotypes sociaux et culturels renforcent le fait que les femmes ont une plus grande responsabilité envers leur famille et leur foyer que les hommes, et par conséquent, elles ne sont pas en mesure de rester en contact après la journée de travail formelle, même si elles le souhaitaient. C'est particulièrement le cas des mères célibataires pour qui le droit à la déconnection pourrait avoir un impact positif proportionnellement plus important que pour les autres travailleurs.

Dans cet article, nous examinons comment les relations structurelles et sociales mentionnées ci-dessus, auxquelles les femmes participent et qu'elles vivent, sont liées à l'environnement de travail numérique et au droit à la déconnection. Nous accordons une attention particulière à l'équilibre entre la vie privée et professionnelle et à un partage équitable des responsabilités familiales et ménagères.

Mots-clés: travail à distance, pandémie, droit à la déconnection, égalité des sexes, discrimination 
Remote Work During the COVID-19 Pandemic and the Right to Disconnect...

\title{
Praca zdalna podczas pandemii COVID-19 i prawo do bycia offline - konsekwencje dla udziału kobiet w cyfrowym świecie pracy
}

\author{
Streszczenie
}

Dostęp do najnowszych technologii jest kluczowy dla osiągnięcia integracji cyfrowej. Jednak w wielu krajach, w tym w gospodarkach krajów należących do grupy G20, nierówności strukturalne (np. w zakresie dochodów, wykształcenia i możliwości zatrudnienia), zwiększają bariery w dostępie do technologii i możliwości jej wykorzystania, których kobiety mogą doświadczać bardziej dotkliwie niż mężczyźni. Wśród rozwiązań ułatwiających kobietom działalność zarobkową często promuje się elastyczne formy pracy (w tym pracę zdalną). Przeprowadzone w kilku krajach badania pokazują jednak, że świat pracy cyfrowej może jeszcze bardziej scementować tradycyjne role płciowe. Nierówność płci w sferze cyfrowej została uznana za poważną przeszkodę na drodze do osiągnięcia sprawiedliwości społecznej, zwłaszcza że Czwarta Rewolucja Przemysłowa nadal zwiększa tempo zmian technologii informacyjnych i komunikacyjnych. W miarę postępującego uzależniania społeczeństw od technologii cyfrowych, wizja pełnego uczestnictwa kobiet w gospodarkach cyfrowych oddala się.

Raporty dochodzące z różnych stron świata pokazują że podczas kryzysu wywołanego pandemią COVID-19 wspomniane nierówności ulegają pogłębieniu, że w skali globalnej kobiety dotknięte są skutkami społeczno-ekonomicznymi pandemii w stopniu większym niż mężczyźni. Wiele kobiet zmuszonych jest łączyć wzrost nieodpłatnej opieki z wymaganiami pracy zarobkowej, która teraz najczęściej przyjmuje nowe formy (cyfrowy świat pracy, praca zdalna) wraz z ich konsekwencjami. Konieczność godzenia aktywności zawodowej i życia rodzinnego odciska się poważnym piętnem na dobrostanie kobiet.

Przed pandemią COVID-19 kobiety na całym świecie wykonywały prawie trzy razy więcej nieodpłatnej opieki i pracy domowej niż mężczyźni. Po wybuchu pandemii, nakład pracy opiekuńczej $\mathrm{w}$ domu wzrósł wykładniczo. Kobiety nie tylko stają przed bezpośrednimi wyzwaniami, jakie niesie pandemia, lecz jednocześnie doświadczają pogłębiających się nierówności. W szczególności zamknięcie szkół i przedszkoli ujawniło, jak nietrwały jest udział kobiet w gospodarce zarobkowej. Zamknięcie instytucji sprawujących opiekę na dziećmi oraz izolacja domowa przeniosły prace opiekuńczą z płatnej sfery gospodarki (przedszkola, szkoły, opiekunki do dzieci) do sfery aktywności niezarobkowej. Tutaj należy upatrywać źródła wielu nierówności doświadczanych przez kobiety. Podczas gdy zarówno kobiety jak i mężczyźni na całym świecie dotkliwie odczuwają ekonomiczne skutki pandemii, to kobiety doznają o wiele większego skrępowania w sferze działalności zarobkowej.

Idea prawa do rozłączenia się (przejścia w tryb offline) ma na celu wyznaczenie granic korzystania z komunikacji elektronicznej po godzinach pracy i zapewnienie pracownikom prawa do nieangażowania w wykonywanie czynności związanych z pracą zawodową podczas przebywania w domu. Prawo to jest często rozumiane nie tylko jako prawo do przejścia w tryb offline; umożliwia ono również uniknięcie nagany za brak kontaktu oraz eliminuje nagradzanie pracownika za stałe pozostawanie w kontakcie.

Role i stereotypy społeczne i kulturowe powoduja, że kobiety ponoszą większą odpowiedzialność za swoje rodziny i dom niż mężczyźni i mogą nie być w stanie pozostać w kontakcie po zakończeniu formalnego dnia pracy, nawet jeśli by tego chciały. Dotyczy to w szczególności matek samotnie wychowujących dzieci, dla których prawo 
do przejścia w tryb offline mogłoby mieć proporcjonalnie większy pozytywny wpływ niż w przypadku innych pracowników.

W artykule zastanawiamy się, w jaki sposób wskazane wyżej relacje strukturalne i społeczne, w których uczestniczą i których doświadczają kobiety, wiążą się z cyfrowym środowiskiem pracy i prawem do przejścia w tryb offline. Zwracamy szczególną uwagę na równowagę między pracą zawodową i życiem rodzinnym oraz na sprawiedliwy podział obowiązków rodzinnych i domowych.

Słowa kluczowe: praca zdalna, pandemia, prawo do przejścia w tryb offline, równość płci, dyskryminacja 